RIBEIRO, CSC; SOARES, RS; GOMES, LM; COELHO, LGF; REIFSCHNEIDER, FJB. 2017. Breeding Calabrian pepper lines for Brazilian agriculture from sui generis introduction of germplasm. Horticultura Brasileira 35: 195-202. DOI - http://dx.doi.org/10.1590/S0102-053620170207

\title{
Breeding Calabrian pepper lines for Brazilian agriculture from sui generis introduction of germplasm
}

\author{
Claudia SC Ribeiro ${ }^{1}$; Renato S Soares ${ }^{2}$; Lucas M Gomes ${ }^{3}$; Lucas GF Coelho ${ }^{3}$; Francisco JB Reifschneider ${ }^{4}$ \\ ${ }^{1}$ Embrapa Hortaliças, Brasília-DF, Brasil; claudia.ribeiro@embrapa.br; ${ }^{2}$ Universidade Estadual Paulista (UNESP), Jaboticabal-SP, Brasil; \\ renato_2366@hotmail.com; ${ }^{3}$ Universidade de Brasília (UnB), Brasilia-DF, Brasil; lucasmatyasgomes@gmail.com; lucasferrerv@gmail. \\ com; ${ }^{4}$ Embrapa, Secretaria de Relações Internacionais, Brasília-DF, Brasil; francisco.reifschneider@embrapa.br
}

\begin{abstract}
Few Calabrian pepper cultivars (C. annuum and C. baccatum) are available in the Brazilian market, and among these, only BRS Mari (C. baccatum) was developed in Brazil, by Embrapa. This work aimed to report on the introduction of germplasm in a sui generis way and the initial results of Calabrian pepper breeding at Embrapa Vegetables. Original population was obtained through separation of seeds found in dehydrated Calabrian pepper flakes imported from India. The breeding method was individual selection of plants with progeny test and three generations of selection and self-pollination were advanced. Ten plants were obtained from the original seeds, which were self-pollinated and originated $87 \mathrm{~S}_{1}$ plants. Out of these, seeds of $73 \mathrm{~S}_{1}$ plants were obtained and gave rise to $73 \mathrm{~S}_{2}$ lines. Based on the characteristics of plant and fruit (number of side shoots, weight and total number of fruits, length and width of fruits, wall thickness, color of the ripe fruit, total soluble solids and capsaicin content), three $\mathrm{S}_{2}$ lines were selected and, then, 14 plants within these lines (4 plants of line CNPH 50.112, 5 plants of CNPH 50.116 and 5 plants of CNPH 50.185 ). Significant differences (Tukey, $\mathrm{p}<0.05$ ) were noticed among the $14 \mathrm{~S}_{3}$ lines, for precocity, length and width of the fruit, weight of the fruit, weight and number of fruits per plant. Five $\mathrm{S}_{3}$ lines were selected based on the following criteria: average fruit weight above $12 \mathrm{~g}$, early flowering (less than 80 days after sowing), fruit length above $13 \mathrm{~cm}$ and fruit width around $1.5 \mathrm{~cm}$, dark green color of leaf and sparse or medium pilosity. In the following $\mathrm{S}_{4}$ generation, the selected lines will be evaluated in order to determine yield, disease resistance as well as capsaicinoid concentration in fruits. New genotypes selected may be released as cultivars that meet the growing demand for dehydrated Calabrian pepper flakes.
\end{abstract}

Keywords: Capsicum annuum, selection, pepper flakes, pepperoncino.

\begin{abstract}
RESUMO
Melhoramento de pimenta calabresa através de introdução sui generis de germoplasma
\end{abstract}

São poucas as cultivares de pimenta calabresa (C. annuum e $C$. baccatum) disponíveis no mercado brasileiro, e destas apenas BRS Mari (C. baccatum) foi desenvolvida no Brasil pela Embrapa. Este trabalho teve como objetivo relatar a introdução de germoplasma de modo sui generis e os resultados iniciais do melhoramento genético de pimenta do tipo calabresa da Embrapa Hortaliças. A população original foi obtida pela separação de sementes encontradas em flocos de pimenta calabresa desidratada importada da Índia. O método de melhoramento utilizado foi de seleção individual de plantas com teste de progênie e foram avançadas três gerações por autofecundação e seleção. Das sementes originais foram obtidas 10 plantas que foram autofecundadas e deram origem a 87 plantas $S_{1}$, das quais foram obtidas sementes de 73 plantas, que deram origem a 73 linhagens $S_{2}$. Com base em características de planta e fruto (peso e número total de frutos, comprimento e largura dos frutos, espessura do pericarpo, coloração de fruto maduro, número de brotações laterais, quantidade de solúveis sólidos totais e teor de capsaicina), foram selecionadas três linhagens $\mathrm{S}_{2}$ e dentro delas 14 plantas (4 plantas da linhagem CNPH 50.112, 5 plantas de CNPH 50.116 e 5 plantas de $\mathrm{CNPH}$ 50.185). Foram detectadas diferenças significativas (Tukey, $\mathrm{p}<5 \%$ ) entre as 14 linhagens $\mathrm{S}_{3}$ para precocidade, comprimento e largura de fruto, peso de fruto, peso e número de frutos por planta. Para dar continuidade ao programa de melhoramento, foram selecionadas cinco linhagens $\mathrm{S}_{3}$ com peso médio de frutos acima de $12 \mathrm{~g}$, início de florescimento abaixo de 80 dias após a semeadura, comprimento de fruto acima de $13 \mathrm{~cm}$ e largura de fruto em torno de $1,5 \mathrm{~cm}$, cor de folha verde escuro e pilosidade esparsa ou média. Na próxima geração $\left(\mathrm{S}_{4}\right)$ serão realizados testes para determinar rendimento das linhagens, resistência a doenças assim como análises da concentração de capsaicinoides nos frutos. Os novos genótipos selecionados poderão ser lançados como cultivares que atendam a demanda crescente de pimenta desidratada em flocos.

Palavras-chave: Capsicum annuum, seleção, flocos de pimenta, peperoncino.

Received on January 28, 2016; accepted on October 20, 2016

$\mathrm{T}_{\mathrm{s}}$ he genus Capsicum, represented by hot and sweet peppers, originates from the tropical America, is nowadays widely dispersed and grown all over the world. Capsicum fruits are mainly used for producing spices due to the characteristics of their several compounds which give aroma and flavor (Büttow et al., 2010), as well as pungency, main characteristic of hot or chile peppers. Brazil is an important diversity center of Capsicum, holding domesticated, semi domesticated and wild species (Carvalho et al., 2003; Monteiro et al., 2010). The genus 
consists of about 30 species, only five being considered as domesticated $C$. annuum, C. baccatum, C. frutescens, C. chinense and C. pubescens, the latter being not found in Brazil (Moreira et al., 2006).

The Portuguese and the Spanish introduced Capsicum peppers in Asia and, in the mid-sixteenth century, a variety of pepper called "Pernambuco" was known in Goa (India), a strong indication of its origin (Reifschneider, 2000). Currently, India is a great grower and exporter of dehydrated red pepper fruit (C. annиum), whole or in form of flakes (Kumar \& Rai, 2005; Rathore \& Shekhawat, 2008). In 2013, India produced about 1.4 million metric tons of dehydrated peppers and exported, in 2011, 260 thousand metric tons of dried peppers (FAO, 2015). Numerous landraces and local population of different kinds of Capsicum peppers are grown in India (Bosland \& Baral, 2007), and most of them belong to $C$. annuum species (Kumar \& Rai, 2005). Due to natural great variability, India is known as a secondary center of diversity for Capsicum (Kumar \& Rai, 2005).

Cultural and economic importance of Capsicum in Brazil is high and hot pepper crops yield good returns, employing a large amount of labor, mainly during harvest and fruit processing (Moreira et al., 2006; Domenico et al., 2012). These are some of the key reasons the crop is attractive to small farmers, helping diversify income source and reducing rural exodus (Moreira et al., 2006).

C. annuum fruits have high commercial value and they are among the ten most consumed vegetables in Brazil (Moreira et al., 2006; Rocha et al., 2006). This species is represented by sweet peppers, peppers for paprika and hot peppers like jalapeño, cayenne, serrano, cherry, among others, besides ornamental varieties (Reifschneider, 2000; Büttow et al., 2010). C. апnиum fruits are consumed green and ripe, in natura, in sauces or dehydrated. Calabrian pepper, also known as peperoncino, generally belongs to this species and is widely used in Italian cuisine, particularly in regions of Sicily and Sardinia. The region of Calabria, in Southern Italy, is an important producer and consumer of fresh and dehydrated pepper (Silva, 2015). With mild to medium pungency, peperoncino fruits are often used for seasoning meats and giving special flavor to sauces.

In Brazil, Calabrian pepper is not a kind of pepper that belongs to a determined species, but rather it is a product from red pepper dehydration in form of flakes, being frequently used as a spice for food processing industry. Brazilian Calabrian pepper is obtained from red ripe fruits, mainly from $C$. baccatum and $C$. annuum. Fruits are harvested when ripe and dried in the sun on tarps or in dryers with forced hot air circulation. Once dried, the whole fruits are flaked, including the seeds (Ribeiro et al., 2008). Seeds, pericarp and pieces of pulp that are separated during processing of sauces, by medium and large sized agroindustries, are also used as "Calabrian pepper" in processed food.

In the 2004/2005 harvest, the city of Turuçu (Rio Grande do Sul), known as the national capital of red chile pepper, was considered the largest producer of red C. baccatum pepper for flakes, with 70 hectares planted to the crop and an average yield of $13 \mathrm{t} /$ ha of fresh fruits (Madail et al., 2005). In the 2011/2012 harvest, Turuçu had only 15 hectares planted by about 20 producers, with yield of $1,500 \mathrm{~kg}$ of dry pepper per hectare and total production estimated of $22 \mathrm{t}$ (Secretaria Municipal de Agricultura de Turuçu, RS, 2015). Planting area in 2014/2015 was only six hectares and, to the next harvest, the expected area is four hectares. Fungal diseases and low price are pointed out as the main reasons for the drastic reduction in cultivation area of Calabrian pepper in Turuçu (Schneider, LF, personal communication).

There are few cultivars of chile pepper (C. annuum and C. baccatum) available in the Brazilian market that could be used to obtain Calabrian pepper, like 'BRS Mari' (Agrocinco, 2015), 'de Cayenne' pepper and hybrid 'Grisu F1' (Isla, 2015), 'Caliente' and 'Pic Nik' hybrids (Sakama, 2015), Cayenne 'Dedo-de-Moça' (Feltrin, 2015) and the peppers type "dedode-moça" (Agristar, 2015; Hortivale, 2015). Out of these cultivars, only
'BRS Mari' (C. baccatum) originated from a Brazilian breeding program, implemented by Embrapa Vegetables (Carvalho et al., 2009).

The development of new cultivars heavily depends on the genetic resources available, collected and characterized, in collections or germplasm banks (AGB) (Nass, 2007). The enrichment of an AGB is normally carried out through germplasm exchange among research institutions, collecting expeditions and acquisition of commercial seeds available in the market. However, in the specific case of Calabrian pepper accession CNPH 50.000, belonging to the Capsicum collection of Embrapa Vegetables, the germplasm was introduced in a sui generis way: seeds were obtained from a small batch of the commercial product Calabrian pepper (dehydrated red pepper flakes with seeds) from India, evaluated by an agroindustry as excellent quality. In 2014, Brazil imported 1,364 metric tons of Capsicum peppers, worth about US\$ 3.5 million, and India is one of the main exporters (SECEX, 2015).

The absence of national cultivars of Calabrian pepper (C. annuum) adapted to different Brazilian biotic and abiotic conditions motivated the beginning of this research in Embrapa Vegetables. This work aimed to report results of breeding research of Calabrian pepper (C. annuиm), from the population $\mathrm{CNPH}$ 50.000 , as well as the identification and selection of plants and lines with promising agronomic characteristics for developing new cultivars of interest to Brazilian agriculture.

\section{MATERIAL AND METHODS}

Localization: This work was carried out at Embrapa Vegetables, located on Rodovia BR-060, km 09, Brasília, Federal District, Brazil (15'55'57'S, 48 $8^{\circ} 11^{\prime \prime} \mathrm{W}$ ).

Genotype used: The seeds of $C$. annuиm that allowed the beginning of this work were obtained from a small sample of dehydrated pepper flakes (Calabrian type) imported from India, courtesy of a Brazilian company of pepper-based products. Seed 
samples were introduced in Capsicum Germplasm Bank as CNPH 50.000. This batch of pepper in flakes showed capsaicin content of 32,100 Scoville Heat Units (SHU).

Breeding methodology: The breeding method used was individual selection of plants with progeny test. This method is based on variability already existing in the population (Allard, 1971; Borém, 1998).

Original seeds were sown in styrofoam trays with 72 cells and the seedlings obtained were transplanted into 10 -liter pots; the 10 plants obtained (original plants) were maintained in a screenhouse and were hand selfpollinated. From each plant, 3-5 selfpollinated fruits were harvested and extracted seeds were submitted to pre-drying $\left(48\right.$ hours at $32^{\circ} \mathrm{C}$ ), and then dried in a forced air oven (Soc. FABBE. Ltda. Model: 171) for 24 hours at $40^{\circ} \mathrm{C}$.

For the following cycle, ten $\mathrm{S}_{1}$ seeds from each of the 10 original selfpollinated plants were used. $\mathrm{S}_{1}$ seeds were sown in trays of 72 cells filled with substrate Tropstrato (Vida Verde ${ }^{\odot}$ ). $\mathrm{S}_{1}$ seedlings obtained (87 plants) were transplanted into $350 \mathrm{~mL}$ pots and later into 10 -liter pots, containing a mixture of sterilized soil, carried out 38 days after sowing.

In the flowering phase, selfpollination was carried out in all $87 \mathrm{~S}_{1}$ plants obtained. Fruits with 60 days after self-pollination were harvested and open pollinated (OP) fruits were harvested from plants without self-pollinated fruits due to abortion of self-pollinated flowers. After harvest, seeds were dried using the process previously described. Self-pollinated seeds of 43 plants and OP seeds of 30 plants were obtained (73 lines). The OP seeds harvested were also considered $\mathrm{S}_{2}$ because chile peppers grown in aphid-proof screenhouses maintain insects away from flowers and fruit is considered self-pollinated (DeWitt \& Bosland, 2009).

In the next generation, five seeds from each of the $73 \mathrm{~S}_{2}$ lines obtained in the previous generation were sown in trays of 72 cells, filled with substrate Carolina Padrão (organic, http://www. carolinasoil.com.br/). A total of $327 \mathrm{~S}_{2}$ plants (4-5 plants/line) were transplanted to a screenhouse, directly in the soil, at 54 days after sowing. Plant spacing used was $1.2 \mathrm{~m}$ between rows and 0.9 $\mathrm{m}$ between plants. Before transplanting, the area was fertilized with NPK (4:14:8) based on results of soil analysis.

Fourteen plants (4 plants of CNPH $50.112,5$ plants of CNPH 50.116 and 5 plants of CNPH 50.185) were selected among and within $\mathrm{S}_{2}$ lines. Self-pollinated fruits from selected lines were harvested separately, plant by plant. $\mathrm{S}_{3}$ seeds of these fruits were extracted and submitted to the same drying process that was carried out for previous generations. In 2015, seeds from $\mathrm{S}_{3}$ were sown and seedlings obtained as previously described and $14 \mathrm{~S}_{3}$ selected lines were taken to the field, 5 plants per plot, in two completely randomized replications, for a preliminary evaluation of agronomic and processing characteristics of interest (pilosity, earliness, number of side shoots, color of leaves and unripe fruit, plant height, fruit length and diameter, wall thickness, weight of individual fruit, total number and weight of fruits per plant), and identification of lines adapted to Central Brazil. Concomitantly, three plants from each line were maintained in a screenhouse for controlled self-pollination.

Agronomic and processing characterization: A preliminary characterization of fruits was carried out (up to three fruits per plant) from ten plants of original population (CNPH $50.000)$ based on the fruit traits: length $(\mathrm{cm})$, diameter $(\mathrm{cm})$, wall thickness $(\mathrm{mm})$ and number of locules.

Fruit of the $73 \mathrm{~S}_{2}$ lines were also preliminarily evaluated (one fruit per plant, 5 fruits per line) for length $(\mathrm{cm})$ and width $(\mathrm{cm})$, wall thickness $(\mathrm{mm})$ and fruit weight $(\mathrm{g})$, and also color of unripe fruit. Due to great variation in number of side shoots among lines, the number of shoots of each plant was counted (for all lines). $\mathrm{S}_{2}$ lines were grouped into five classes: class 1: 1-2 shoots per plant; class 2: 3-4 shoots per plant; class 3: 5-6 shoots per plant; class 4: 7-8 shoots per plant; and class 5: 9-10 shoots per plant.

In addition, a subjective evaluation of agronomic value of $\mathrm{S}_{2}$ plants was carried out, by at least two evaluators, who based the evaluation on the structure of plant (architecture) and production of fruits (estimated visually). Based on quantitative data obtained and qualitative evaluation of agronomic value of plants, three $\mathrm{S}_{2}$ lines were selected. The three selected lines were also evaluated for number of fruits per plant, total weight of fruits $(\mathrm{g})$, total soluble solids ( ${ }^{\circ}$ Brix), capsaicin content and color of ripe fruit ( 5 fruits of each plant).

Parameters fruit length, width and wall thickness were measured using a digital caliper MITUTOYO, model 500-144B. To determine total soluble solids ( $\left.{ }^{\circ} \mathrm{Brix}\right)$, a digital refractometer ATAGO model PR-1 was used, following standard methodology to clean the equipment and to standardize the samples.

\section{Determination of capsaicin:} Determination of capsaicin content of three selected $\mathrm{S}_{2}$ lines was carried out using AOAC Official Method 995.03 (AOAC, 2006) that can be used to determine capsaicinoids content between 750 and 650,000 Scoville Heat Units (SHU).

Determination of fruit color: Analyses of unripe and ripe fruit color were carried out. For analysis of unripe fruit, one fruit from each plant was harvested, from all lines, and a reading per fruit was carried out. Analysis of ripe fruit color was carried out only for the three selected lines (five fruits per plant and a reading per fruit). Color analysis was carried out by using colorimeter (Minolta Chromometer Model CR-400), standard CIE-L*a*b*. Coordinate $\mathrm{L}$ is related to fruit luminosity (corresponding to variation from white to black); coordinate $\mathrm{a}^{*}$ corresponds to horizontal axis, $a^{*}$ positive tending to red and $\mathrm{a}^{*}$ negative tending to green; coordinate $b^{*}$ corresponds to vertical axis, $b^{*}$ positive tending to yellow and $b^{*}$ negative to blue. Color measurements were carried out in equatorial region of each fruit.

Statistical analyses: Data analyses of fruit characterization in the original population was based on t-test; for the number of locules, Kruskall-Wallis was utilized. In $\mathrm{S}_{2}$ generation the t-test was 
used for the analysis of all parameters. Capsaicin values were not analysed statistically due to low number of replications. Mean of side shoots and number of fruits per plant were adjusted by the least squares method $(\sqrt{\mathrm{x}+0,5})$. For the $14 \mathrm{~S}_{3}$ lines, the statistical analysis used was Tukey at $\mathrm{p}=5 \%$.

\section{RESULTS AND DISCUSSION}

\section{Evaluation of original population}

Evaluation of characteristics of fruits and plants obtained from the original population (CNPH 50.000) that came from Indian Calabrian pepper showed significant variability among individuals. Significant differences were observed through t-test $(p<0.05)$ for characteristics fruit length, fruit diameter and wall thickness, which ranged from 6.6 to $11.6 \mathrm{~cm}, 0.76$ to 1.15 $\mathrm{cm}$ and 0.84 to $1.39 \mathrm{~mm}$, respectively. No significant differences were found for number of locules (Table 1).

Presence of variability in original population is essential for selecting individuals with superior characteristics. Success in development of new cultivars is directly associated to genetic variability of the population to be improved (Cardoso, 2001; Nass, 2007; Ribeiro et al., 2008). Genus Capsicum has significant genetic variability (Inoue $\&$ Reifschneider, 1989), and among the domesticated species, C. annuиm has greater diversity, whereas $C$. frutescens has less variability (Casali \& Couto, 1984).

\section{Evaluation of $S_{2}$ lines}

Significant differences among the $73 \mathrm{~S}_{2}$ lines were observed for all fruit characteristics evaluated. Values of fruit weight ranged from 2.3 to $10.9 \mathrm{~g}$; fruit length ranged from 7.5 to $13.4 \mathrm{~cm}$; fruit diameter ranged from 0.7 to $1.4 \mathrm{~cm}$ and wall thickness ranged from 0.87 to $1.98 \mathrm{~mm}$. Some of these values are close to the most cultivated variety of $C$. annuum pepper grown in India, known as "Pusa Jwala," which presents fruit length ranging from 7 to $13 \mathrm{~cm}$, fruit width from 1 to $1.5 \mathrm{~cm}$ and pungency between 30,000-50,000 SHU (DeWitt \& Bosland, 2009).
Pigments in vegetables are nutritionally important and those with high chlorophyll content (dark green) are sources of provitamin A (Gross, 1991). According to Kim et al. (2011), several phytochemicals, including those found in pepper leaves, such as lutein, chlorophyll and tocopherol, might be used in nutraceuticals and pharmaceuticals for improving human health (Kim et al., 2011). Furthermore, there is a positive correlation between the green color, the chlorophyll concentration and the carotenoid concentration, i.e., the darker the fruits and vegetables are, the higher is their carotenoid concentration (Nollet \& Toldrá, 2012). Therefore, immature fruit color in addition to mature fruit color, is a parameter that also needs to be taken into consideration by Capsicum breeding programs. Color of unripe fruits in the $73 \mathrm{~S}_{2}$ lines ranged from $\mathrm{L}^{*}=26.55 ; \mathrm{a}^{*}=-21.62 ; \mathrm{b}^{*}=6.44$ to $\mathrm{L}^{*}=$ $60.82 ; a^{*}=-5.86$ and $b^{*}=42.19$. Figure 1 shows color space observed in these 73 lines; differences in the intensity of the green color among fruits could be visually verified (light green and dark green). Color of ripe fruits, however, did not show variation noticeable to the naked eye, and due to this fact, they were not evaluated quantitatively. In relation to side shoots, only one line in class $1(1 \%)$ was observed; six lines in class $2(8 \%) ; 26$ lines in class $3(36 \%)$; 32 lines in class 4 (44\%); and eight lines in class $5(11 \%)$
(Figure 2). A fewer number of side shoots requires less labor for thinning and for fruit harvest. Besides, it also allows a higher level of ventilation and decreases humidity in the microclimate formed around the plants, favoring a better phytosanitary condition. There was a significant negative correlation $(p<0.05)$ between number of side shoots and average fruit weight, as well as number of side shoots and fruit length; no significant correlation was detected between number of side shoots and fruit diameter. Increase of pruning levels on $C$. chinense pepper plants with consequent decrease of side shoots, resulted in an increase of fruit weight (Jaimez et al., 2002). The authors also suggest that with lower amount of shoots, change in distribution of nutrients assimilated by different parts of the plant may have happened. Alsadon $e t$ al. (2013) reported a significant increase of size and quality of fruits due to pepper plant pruning, keeping only one branch. Density and number of pruning operations per plant are important factors for Capsicum production, both under protected cultivation as well as under field conditions. Dasgan \& Abak (2003) concluded that peppers grown in a greenhouse with high plant density and reduced number of side shoots per plant increased significantly the yield per $\mathrm{m}^{2}$. McCraw \& Greig (1986) observed higher yield per plant and fruit weight through pruning peppers grown in field conditions.

Table 1. Average values of length (FL), diameter (FD), wall thickness (WT) and number of locules (NL) in pepper fruits from the original plants of Calabrian pepper fruits (CNPH 50.000). Brasília, Embrapa Vegetables, 2013.

\begin{tabular}{|c|c|c|c|c|}
\hline CNPH number & FL $(\mathrm{cm})$ & FD $(\mathrm{cm})$ & WT (mm) & NL \\
\hline 50.001 & $10.3 \mathrm{ab}^{1}$ & $1.05 \mathrm{abc}$ & $1.17 \mathrm{abc}$ & 2.0 \\
\hline 50.002 & $6.6 \mathrm{~d}$ & 0.88 & $1.14 \mathrm{abcd}$ & 2.0 \\
\hline 50.003 & $10.9 \mathrm{a}$ & 0.92 & $1.06 \mathrm{bcd}$ & 2.0 \\
\hline 50.004 & $11.6 \mathrm{a}$ & $1.13 \mathrm{ab}$ & $1.28 \mathrm{ab}$ & 2.0 \\
\hline 50.005 & $8.6 \mathrm{bcd}$ & 0.96 abcd & 0.97 & 2.0 \\
\hline 50.006 & $9.9 \mathrm{abc}$ & $1.06 \mathrm{abc}$ & $1.14 \mathrm{abcd}$ & 2.0 \\
\hline 50.007 & 7.6 & 0.76 & 0.84 & 2.0 \\
\hline 50.008 & $9.4 \mathrm{abc}$ & $0.94 \mathrm{bcd}$ & 0.89 & 2.0 \\
\hline 50.009 & $8.6 \mathrm{bcd}$ & 0.78 & 0.97 & 2.0 \\
\hline 50.010 & 7.0 & $1.15 \mathrm{a}$ & $1.39 \mathrm{~A}$ & 2.3 c \\
\hline CV (\%) & 14.6 & 12.5 & 14.6 & \\
\hline
\end{tabular}

${ }^{1}$ Means followed by the same letter in the column do not differ significantly by t-test $(p<0.05)$. 


\section{Evaluation of selected $S_{2}$ lines}

In quantitative evaluation, the selected lines CNPH 50.112, CNPH 50.116 and CNPH 50.185 showed significant differences for the characteristics side shoots, total number and weight of fruits per plant, average fruit weight, length and diameter of the fruit, capsaicin content and color of unripe and ripe fruit (Table 2). The three lines showed fruit length between 9.4 and $10.7 \mathrm{~cm}$, fruit diameter between 0.9 and $1.2 \mathrm{~cm}$. In Brazil, C. annuum cultivars 'Calabrian' peppers (Isla, 2015) and 'Cayenne Dedo-de-Moça' (Feltrin, 2015) present fruit size of 8-12 x 1-2 cm and $12 \times 1 \mathrm{~cm}$, respectively, values close to selected lines. Besides, CNPH 50.112 showed better plant architecture and good fruit yield; CNPH 50.116 showed absence of side shoots and smaller size plants and CNPH 50.185 stood out among others for its excellent fruit yield, color and shape of fruits. Among the three lines, $\mathrm{CNPH}$ 50.185 showed highest average values for total number and weight of fruits per plant, 283 fruits and 1,122 g per plant, respectively. CNPH 50.112 and CNPH 50.116 were less productive, with average of 105 and 97 fruits/plant, respectively (Table 2). The large number of fruits showed by CNPH 50.185 can be attributed to its high number of side shoots, since a positive correlation between number of fruits and side shoots can be noticed. Dasgan \& Abak (2003) obtained variation of approximately $230 \%$ in number of fruits per plant when cultivation with one shoot was carried out (spacing of $80 \mathrm{~cm}$ between lines $x 15$ $\mathrm{cm}$ between plants) and four side shoots per plant (spacing of $80 \mathrm{~cm} \times 45 \mathrm{~cm}$ ), in a greenhouse.

CNPH 50.112 and CNPH 50.116 did not differ statistically for length, diameter and wall thickness of fruits. The three Calabrian pepper selected lines showed fruit length greater than the paprika pepper cultivars and 'BRS Mari' ( 5.4 to $6.3 \mathrm{~cm}$ ), evaluated by Paulus $e t$ al. (2015).

Regarding the color, ranges of values found for unripe fruits of $73 \mathrm{~S}_{2}$ lines as well as for unripe and ripe fruits of the three selected lines are shown in Figure 1. CNPH 50.185 showed the highest

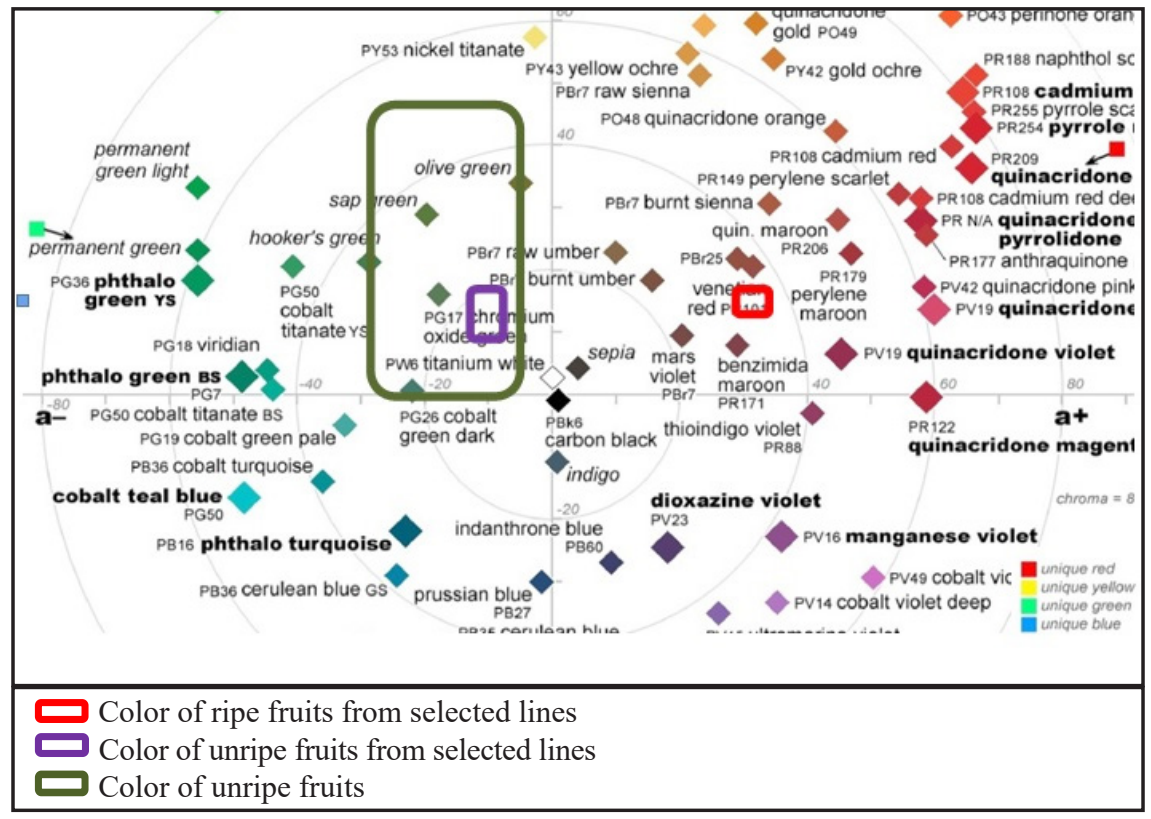

Figure 1. Pigment and color illustration with $\mathrm{a}^{*} \mathrm{~b} *$ values of unripe fruits of Calabrian pepper $\mathrm{S}_{2}$ lines and color of unripe and ripe fruits of three selected lines. Source: CIELAB, 2008. Brasília, Embrapa Vegetables, 2014.

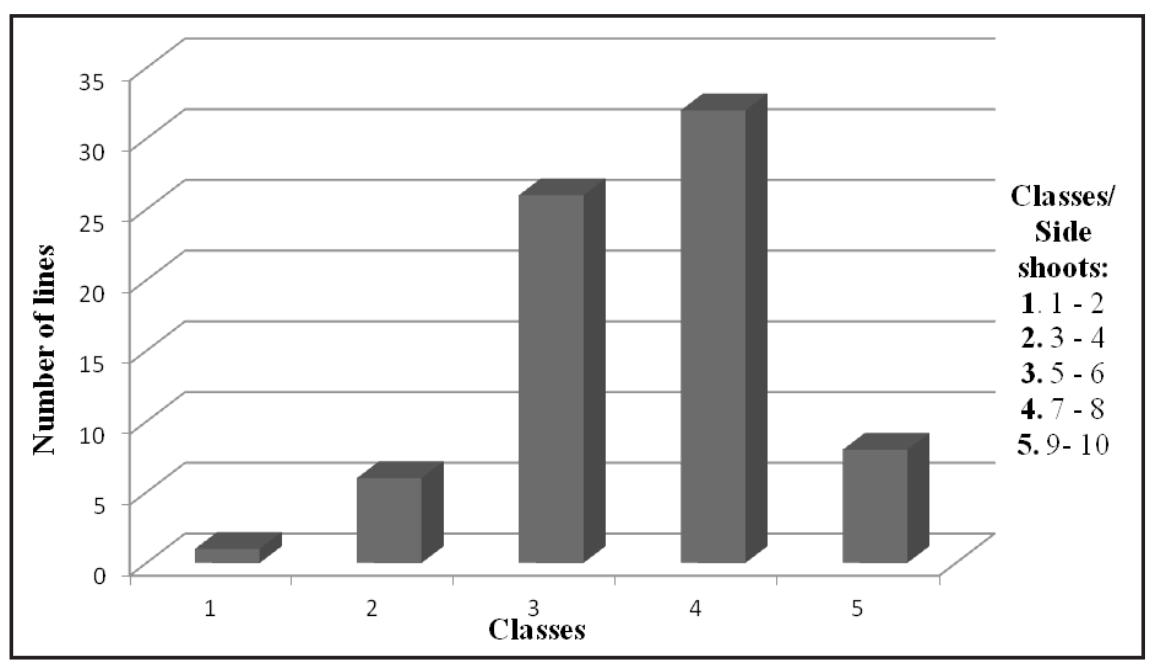

Figure 2. Number of side shoots of $73 \mathrm{~S}_{2}$ Calabrian pepper lines: average values distributed in shoot number classes. Brasília, Embrapa Vegetables, 2014.

values in $\mathrm{L}^{*} \mathrm{a} \mathrm{b}^{*}$ color space, differing statistically from other selected lines, showing unripe fruits with intense/dark green color and ripe fruits with intense bright red color. According to CIELAB chart for colors and pigments (Figure $1)$, which considers $a^{*} b^{*}$ values, CNPH 50.185 showed color similar to the pigment Chromium oxide green for unripe fruits; and color similar to the pigment Venetian red for ripe fruits. Even differing statistically from the lines CNPH 50.112 and CNPH 50.116, for both color of unripe and ripe fruit, the range of values of three lines represented on CIELAB chart was not wide and the color observed in ripe fruits meets the market-required standards. According to Lutz \& Freitas (2008), colors of pepper fruits come from carotenoid pigments, which for its nutritional value, are among the most important plant pigments. Ripe, red Capsicum pepper fruits have 60 times more carotenoids than green fruits, besides having higher concentration of flavonoids and other 
Table 2. Average values of side shoots (SS), total number of fruits per plant (TFP), average fruit weight (FW), fruit length (FL), fruit diameter (FD), wall thickness (WT), total weight of fruits per plant (WFP), unripe fruit color, ripe fruit color, total soluble solids content $\left({ }^{\circ}\right.$ Brix) and capsaicin content (SHU) of three selected $\mathrm{S}_{2}$ lines. Brasília, Embrapa Vegetables, 2014.

\begin{tabular}{|c|c|c|c|c|c|c|c|c|c|c|c|c|c|c|c|}
\hline \multirow{3}{*}{$\begin{array}{l}\text { CNPH } \\
\text { number }\end{array}$} & \multirow{3}{*}{ SS } & \multicolumn{14}{|c|}{ Fruits } \\
\hline & & \multirow{2}{*}{ TFP } & \multirow{2}{*}{$\begin{array}{r}\text { FW } \\
\text { (g) }\end{array}$} & \multirow{2}{*}{$\begin{array}{c}\text { FL } \\
(\mathrm{cm})\end{array}$} & \multirow{2}{*}{$\begin{array}{l}\text { FD } \\
(\mathrm{cm})\end{array}$} & \multirow{2}{*}{$\begin{array}{l}\text { WT } \\
(\mathrm{mm})\end{array}$} & \multirow{2}{*}{$\begin{array}{c}\text { WFP } \\
\text { (g) }\end{array}$} & \multicolumn{3}{|c|}{ Unripe color } & \multicolumn{3}{|c|}{ Ripe color } & \multirow{2}{*}{${ }^{0}$ Brix } & \multirow{2}{*}{ SHU } \\
\hline & & & & & & & & $\mathbf{L}^{*}$ & $a^{*}$ & $\mathbf{b}^{*}$ & $\mathbf{L}^{*}$ & $a^{*}$ & $\mathbf{b}^{*}$ & & \\
\hline 50.112 & $3 b^{1}$ & $105 \mathrm{~b}$ & $6.8 \mathrm{a}$ & $10.6 \mathrm{a}$ & $1.2 \mathrm{a}$ & $1.3 \mathrm{a}$ & $647 \mathrm{~b}$ & $31.8 \mathrm{~b}$ & $-10.0 b$ & $11.2 \mathrm{~b}$ & $37.8 \mathrm{a}$ & $36.6 \mathrm{~b}$ & $19.4 \mathrm{ab}$ & $11.6 \mathrm{a}$ & 5,246 \\
\hline 50.116 & $0.3 \mathrm{c}$ & $97 \mathrm{~b}$ & $6.4 \mathrm{a}$ & $10.7 \mathrm{a}$ & $1.1 \mathrm{a}$ & $1.4 \mathrm{a}$ & $600 \mathrm{~b}$ & $31.4 \mathrm{~b}$ & $-8.5 b$ & $9.2 \mathrm{~b}$ & $37.6 \mathrm{a}$ & $36.7 \mathrm{~b}$ & $19.2 \mathrm{~b}$ & $10.6 \mathrm{a}$ & 5,420 \\
\hline 50.185 & $6 \mathrm{a}$ & $283 \mathrm{a}$ & $4,7 \mathrm{~b}$ & $9.4 \mathrm{~b}$ & $0.9 \mathrm{~b}$ & $1.2 \mathrm{a}$ & $1122 \mathrm{a}$ & $36.5 \mathrm{a}$ & $-14.8 \mathrm{a}$ & $18.7 \mathrm{a}$ & $36.9 \mathrm{~b}$ & $39.1 \mathrm{a}$ & $20.8 \mathrm{a}$ & $10.8 \mathrm{a}$ & 15,727 \\
\hline CV (\%) & 9.1 & 16.8 & 14.4 & 5.6 & 6.7 & 10.2 & 26.8 & 6.7 & 15.2 & 22.4 & 1.00 & 2.3 & 4.9 & 8.4 & \\
\hline
\end{tabular}

${ }^{1}$ Means followed by the same letter in the column do not differ significantly by the t-test $(\mathrm{p}<0.05)$.

Table 3. Average values for fruit weight (FW), fruit length (FL), fruit diameter (FD), days from sowing until flowering (earliness), total number of fruits per plant (TFP), number of side shoots per plant (SS), and stem pilosity observed in five selected $\mathrm{S}_{3}$ lines and $14 \mathrm{~S}_{3}$ lines evaluated. Brasília, Embrapa Vegetables, 2015.

\begin{tabular}{lccccccc}
\hline Range of average values & FW $(\mathbf{g})$ & FL $(\mathbf{c m})$ & FD $(\mathbf{c m})$ & Earliness & TFP & SS & Pilosity \\
\hline Five selected $\mathrm{S}_{3}$ lines & $12.7-15.9$ & $13.3-15.6$ & $1.4-1.5$ & $70-75$ & $57-60$ & $1.20-1.50$ & Sparse to medium \\
$14 \mathrm{~S}_{3}$ lines & $8.2-15.9$ & $9.7-15.6$ & $1.2-1.5$ & $70-87$ & $17-106$ & $1.20-1.77$ & Sparse to medium \\
\hline
\end{tabular}

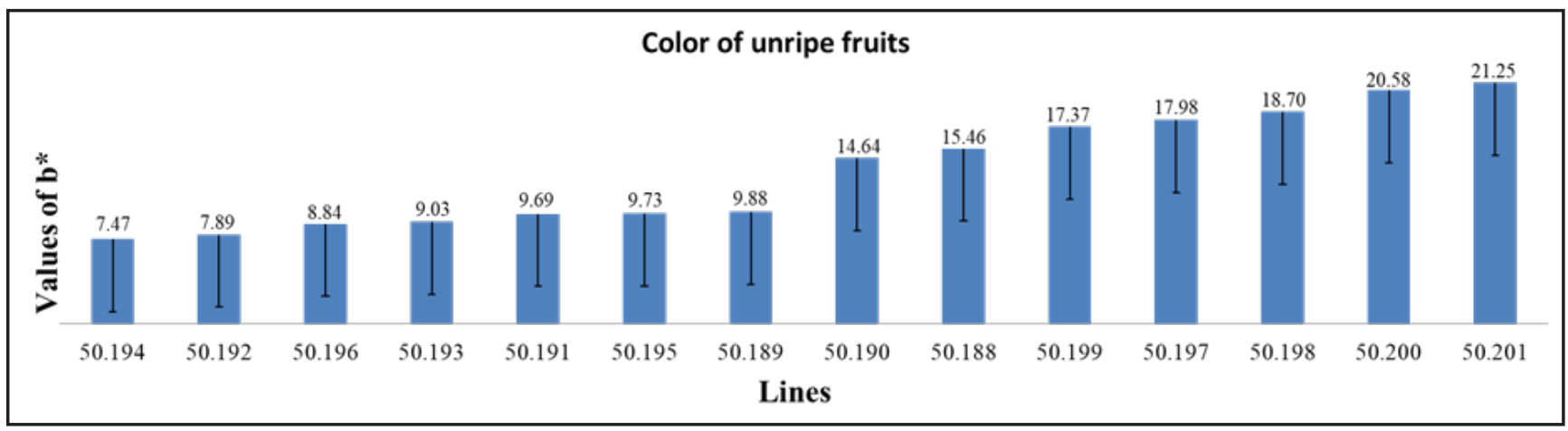

Figure 3. Means of the parameter $b^{*}$ of CIELAB for color of unripe fruits of $14 \mathrm{~S}_{3}$ lines of Calabrian pepper. Brasília, Embrapa Vegetables, 2015 .

secondary compounds (Gómez-García \& Ochoa-Alejo, 2013).

No significant difference among the three selected lines was observed for soluble solid content, which varied from 10.6 to $11.6^{\circ}$ Brix (Table 2). Paulus et al. (2015) observed similar results for soluble solids in paprika cultivars (content of $10.3^{\circ}$ Brix) and BRS Mari (10.2 ${ }^{\circ}$ Brix).

CNPH 50.185 presented capsaicin concentration of 15,700 SHU, differing statistically from lines CNPH 50.112 and CNPH 50.116, with contents of 5,200 and 5,400 SHU, respectively. These values are in the range of pungency of Calabrian pepper flakes. Similar values were found by Ziino et al. (2009) in Calabrian pepper cultivars 'Amando'
(14,700 SHU) and 'Sigaretta' (7,400 SHU).

\section{Evaluation of $\mathrm{S}_{\mathbf{3}}$ lines}

Significant differences were detected $(\mathrm{P}<5 \%)$ among the $14 \mathrm{~S}_{3}$ lines for all parameters evaluated, except for side shoots, plant height and wall thickness. The difference observed in number of side shoots between $\mathrm{S}_{2}$ and $\mathrm{S}_{3}$ generations suggest a high interaction with the environment, since $\mathrm{S}_{2}$ was grown in a screenhouse, and $\mathrm{S}_{3}$ was field grown. Earliness, determined by number of days until flowering, counted from sowing, ranged from 17 days between the earliest line and the latest line, average fruit length ranged from 9.7 to $15.6 \mathrm{~cm}$, average fruit diameter from 1.2 to $1.5 \mathrm{~cm}$, average fruit weight from 8.1 to $15.9 \mathrm{~g}$, average fruit weight per plant from 120 to $730 \mathrm{~g}$ and average number of fruits per plant from 17 to 106 (Table 3) fruits. CNPH 50.199 showed low yield due to a severe attack by Alternaria sp. observed since transplanting into the field. For color of leaf, average values of parameter $b^{*}$ on CIELAB chart ranged from 18.86 to 20.64 for light green and from 12.55 to 14.79 for dark green and for unripe fruits, where a great variation was observed, ranged from 7.47 to 21.25 (Figure 3).

Five of $14 \mathrm{~S}_{3}$ lines (Table 3 ) were selected based on the following characteristics: average fruit weight above $12 \mathrm{~g}$, less than two side shoots per plant, early flowering less than 80 days after sowing, average fruit length 


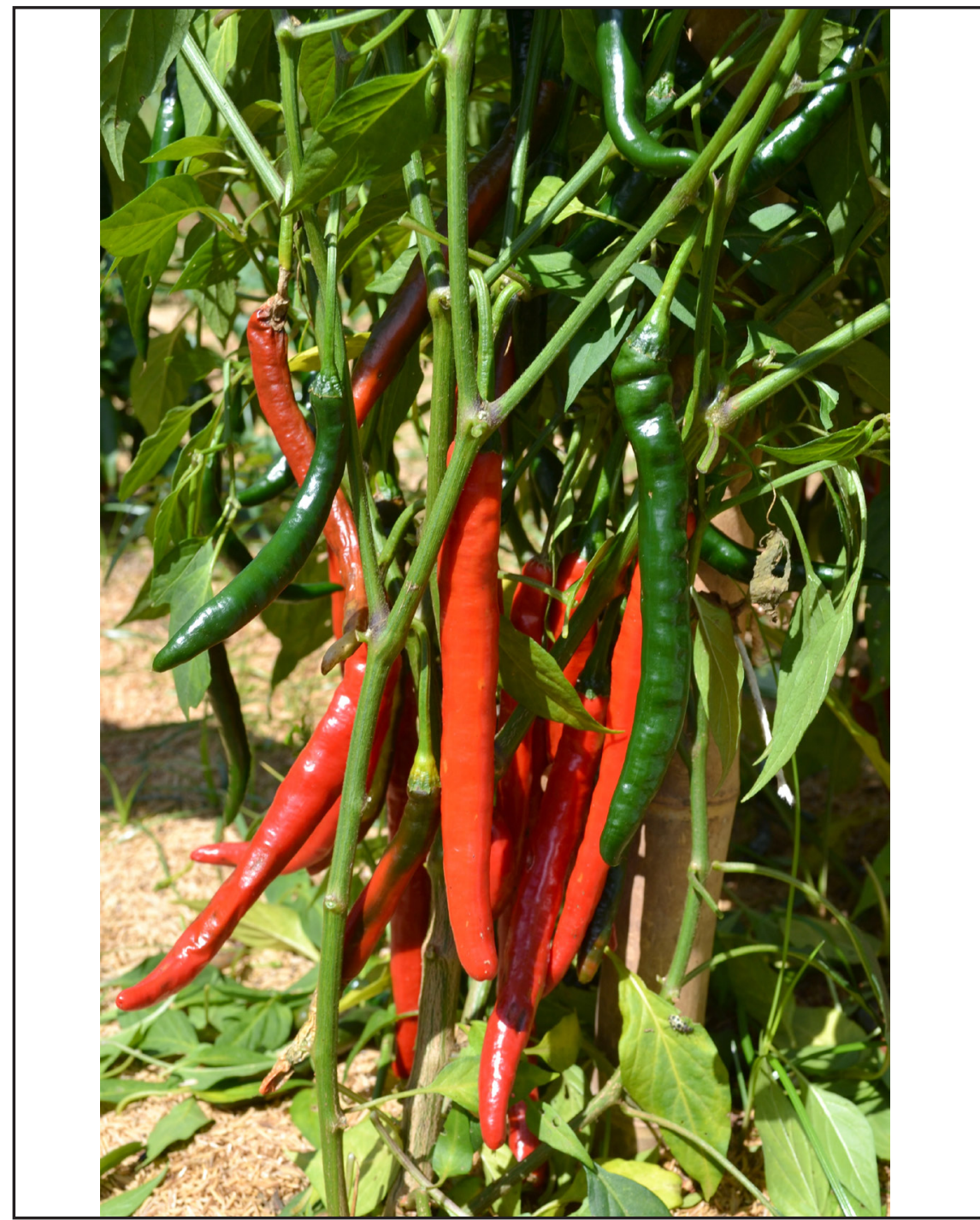

Figure 4. Plant and fruits of the $\mathrm{S}_{3}$ line CNPH 50.189. Brasília, Embrapa Vegetables, 2015.

above $13 \mathrm{~cm}$ and average fruit diameter around $1.5 \mathrm{~cm}$ and dark green leaf; the selected lines did not differ from each other for any of the parameters; and sparse or medium pilosity [CNPH 50.189(Figure 4), 50.192, 50.193, 50.194 and 50.195]. It is interesting to highlight that significant increase of fruit size (length and diameter) and average fruit weight of the five selected $\mathrm{S}_{3}$ lines in relation to the values observed in $\mathrm{S}_{2}$ lines (Table 2) and original plants (Table 1), from which they derived, was observed. Values of average length and diameter of fruits of selected $\mathrm{S}_{3}$ lines are close to the highest values observed in Indian local variety "Pusa Jwala" (C. annuum), 13 and $1.5 \mathrm{~cm}$, respectively (DeWitt \& Bosland, 2009). In the next generation $\left(\mathrm{S}_{4}\right)$, tests under field conditions will be flakes.

\section{ACKNOWLEDGMENTS}

The authors thank Luciano L Nass and Carlos A Lopes for suggestions and review, and Carlos Ragassi for his assistance in statistical analyses.

\section{REFERENCES}

AGRISTAR. 2015. Pimenta Dedo de Moça. Available in http://www.agristar.com. br/topseed/pimenta/dedo-de-moca/135// Accessed on January 25, 2015.

AGROCINCO. 2015. BRS Mari. Available in http://agrocinco.com.br/2013/produto_ detalhes.asp? idprod $=94 \&$ idcat $=16 \&$ idsub $=\overline{0} /$ Accessed on Janeiro 27, 2015.

ALSADON, A; WAHB-ALLAH, M; ABDELRAZZAK, H; IBRAHIM, A. 2013. Effects of pruning systems on growth, fruit yield and quality traits of three greenhouse-grown bell pepper (Capsicum annuиm L.) cultivars. Australian Journal of Crop Science 7: 13091316.

ALLARD, RW.1971. Princípios do melhoramento genético de plantas. São Paulo: Edgard Blüchner, 381p.

AOAC. 2006. Spices and other condiments. Official Methods of Analysis. Chapter 43: 14-15.

BOSLAND, PW; BARAL, JB. 2007. Bhut Jolokia - The world's hottest known chile pepper is a putative naturally occurring interspecific hybrid. HortScience 42: 222-224.

BORÉM, A. 1998. Melhoramento de plantas. Viçosa: Editora UFV, 453p.

BÜTTOW, MV; BARBIERI, RL; NEITZKE, RS; HEIDEN, G; CARVALHO, FIF. 2010. Diversidade genética entre acessos de pimentas e pimentões da Embrapa Clima Temperado. Ciência Rural 40: 1264-1269.

CARDosO, AII. 2001. Melhoramento de Hortaliças. In: NASS, LL; VALOIS, ACC; MELO, IS; VALADARES-INGLIS, MC (eds). Recursos genéticos e melhoramento-plantas. Rondonópolis: Fundação MT. p.293-326.

CARVALHO, SIC; BIANCHETTI, LB; BUSTAMANTE, PG; SILVA, DB. 2003. Catálogo de germoplasma de pimentas e pimentões (Capsicum spp.) da Embrapa Hortaliças. Brasília: Embrapa Hortaliças. 49p. (Documentos, 49).

CARVALHO, SIC; RIBEIRO, CSC; HENZ, GP; REIFSCHNEIDER, FJB. 2009. 'BRS Mari': nova cultivar de pimenta dedo-de-moça para processamento. Horticultura Brasileira 27: 571-573.

CASALI, VW; COUTO, FAA. 1984. Origem e botânica de Capsicum. Informe Agropecuário 113: 8-10.

DASGAN, HY; ABAK, K. 2003. Effects of 
plant density and number of shoots on yield and fruit characteristics of peppers grown in glasshouses. Turkish Journal of Agriculture and Forestry 27: 29-35.

DEWITT, D; BOSLAND, PW. 2009. The complete chile pepper book. Portland:Timber Press, 336p.

DOMENICO, CI; COUTINHO, JP; GODOY, HT; MELO, AMT. 2012. Caracterização agronômica e pungência em pimenta de cheiro. Horticultura Brasileira 30: 466-472.

FELTRIN. 2015. Pimenta Cayenne Dedo de Moça. Available in https://www.sementesfeltrin.com. br/Produto/pimenta-cayenne-dedo-de-moca. Accessed on August 27, 2015.

FAO. Food and Agriculture Organization of the United Nations. 2015. FAOSTAT. Available in: $<$ http://faostat.fao.org $>$. Accessed on April 12, 2015.

GÓMEZ-GARCÍA, MR; OCHOA-ALEJO, N. 2013. Biochemistry and molecular biology of carotenoid biosynthesis in chili peppers (Capsicum spp.). International Journal of Molecular Sciences 14: 19025-19053.

GROSS, J. 1991. Pigments in vegetables: chloropylls and carotenoids. New York: Van Nostrand Reinhold. 351p.

HORTIVAlE. 2015. Pimenta Dedo de Moça. Available in http://www.hortivale.com.br/ pimenta_dedomoca.htm/Accessed on January 25, 2015.

INOUE, AK; REIFSCHNEIDER, FJB. 1989. Caracterização da coleção de germoplasma de Capsicum do CNPH. Horticultura Brasileira 7: 10-18.

ISLA. 2015. Pimenta Híbrida Grisu F1. Available in http://isla.com.br/cgibin/ detalhe.cgi $? \mathrm{id}=221 \&$ grupo_secao $=4 \& \mathrm{id}$ subgrupo $=87 \&$ div $=$ menu_isla_2_4./Accessed on January 25, 2015.

JAIMEZ, RE; NAVA, N; RIVERO, Y; TROMPIZ, K. 2002. Efecto de diferentes intensidades de poda sobre la dinámica de floración y producción de ají dulce (Capsicum chinense,
Jacq). Revista de la Facultad de Agronomía 19: 132-139.

KIM, JI-SUNG; AHN, J; LEE, SUNG-JOON; MOON, B; HA, TAE-YOUL; KIM, S. 2011. Phytochemicals and antioxidant activity of fruits and leaves of paprika (Capsicum annuum L., var. Special) cultivated in Korea. Journal of Food Science 76: 193-198.

KUMAR, S; RAI, M. 2005. Chile in India. Chile Pepper Institute Newsletter xxii: 1-3.

LUTZ, DL; FREITAS, SC. 2008. Valor nutricional. In: RIBEIRO, CSC; LOPES, CA; CARVALHO, SIC; HENZ, GM; REIFSCHNEIDER, FJB (eds). Pimentas Capsicum. Brasília: Embrapa Hortaliças. 200p.

MADAIL, JCM; SCHNEID, LF; SIMA, LF; WENDT, AN. 2005. Economia da produção de pimenta vermelha no município de Turuçu-RS. Embrapa Clima Temperado. 27p. (Boletim de Pesquisa e Desenvolvimento 19).

McCRAW, BD; GREIG, JK. 1986. Effect of transplant age and pruning procedure on yield and fruit-set of bell pepper. HortScience 1986, 21: 430-431.

MONTEIRO, ER; BASTOS, EM; LOPES, ACA; GOMES, RLF; NUNES, JAR. 2010. Diversidade genética entre acessos de espécies cultivadas de pimentas. Ciência Rural 40: 288-283.

MOREIRA, GR; CALIMAN, FRB; SILVA, DJH; RIBEIRO, CSC. 2006. Espécies e variedades de pimenta. Informe Agropecuário 27: 16-29.

NASS, LL. (ed). 2007. Recursos Genéticos Vegetais. Brasília: Embrapa Recursos Genéticos e Biotecnologia. 858p.

NOLLET, LML; TOLDRÁ, F. 2012. Handbook of analysis of active compounds in functional foods. USA: CRC Press. 956p.

PAULUS, D; VALMORBIDA, R; SANTIN, A; TOFFOLI, E; PAULUS, E. 2015. Crescimento, produção e qualidade de frutos de pimenta (Capsicum annuum) em diferentes espaçamentos. Horticultura Brasileira 33: 091-100.
RATHORE, MS; SHEKHAWAT, NS. 2008. Incredible spices of India: from traditions to cuisine. American-Eurasian Journal of Botany 1: 85-89.

REIFSCHNEIDER, FJB. (ed). 2000. Capsicum: pimentas e pimentões no Brasil. Brasília: Embrapa Comunicação para Transferência de Tecnologia/Embrapa Hortaliças. 113p.

RIBEIRO, CSC; LOPES, CA; CARVALHO, SIC; HENZ, GM; REIFSCHNEIDER, FJB. 2008. Pimentas Capsicum. Brasília: Embrapa Hortaliças. 200p.

ROCHA, MC; CARMO, MGF; POLIDORO, JC; SILVA, DAG; FERNANDES, MCA. 2006. Características de frutos de pimentão pulverizados com produtos de ação bactericida. Horticultura Brasileira 24: 185-189.

SAKAMA. 2015. Pimenta Híbrida 'Caliente' e Pimenta Híbrida Pic Nik. Available in http://www.sementesakama.com.br/produtos/ produtos_tradicionais.asp?id=101/ Accessed on January 27, 2015.

SECEX - Secretaria do Comércio Exterior/ Ministério do Desenvolvimento, Indústria e Comércio Exterior. 2015. Available in htpp:// aliceweb.desenvolvimento.gov.br/Acessed on April 20, 2015.

SECRETARIA MUNICIPAL DE TURUÇU, RS. 2015. Available in http://www.turucu.rs.gov. br/portal1/municipio/noticia.asp?iIdMun=10 $0143441 \&$ iIdNoticia $=235696 /$ Accessed on January 15, 2015.

SILVA, C. Pimenta Peperoncino. 2015. Available in http://gastronomiamineiracomcheffsilva. b 1 og s pot.com.br/2010/10/ pimentapeperoncino.html/ Accessed on January 20, 2015.

ZIINO, M; CONDURSO, C; ROMEO, V, TRIPODI, G; VERZERA, A. 2009. Volatile compounds and capsaicinoid content of fresh hot peppers (Capsicum annuum L.) of different Calabrian varieties. Journal of the Science of Food and Agriculture 89: 774-780. 